\title{
Phytochemical Analysis and Radical Scavenging Activity of the Extracts of Costus picatus Linn and Coccinia indica W\& A, two Ethnic Medicinal Plants used in the Treatment of Diabetes mellitus
}

\author{
Ajithabai M D ${ }^{1 *}$, Sreedevi $\mathrm{S}^{1}$, Jayakumar $\mathbf{G}^{1}$, Mangalam S Nair ${ }^{2}$, Deepa P N Nair ${ }^{1}$, Sunitha Rani S P³ \\ ${ }^{1}$ Department of Chemistry, Mahatma Gandhi College, Thiruvananthapuram, 695004, Kerala, India, \\ ${ }^{2}$ NIIST, Thiruvananthapuram, Kerala, India, \\ ${ }^{3}$ Department of Chemistry, Christian College, Kattakkada, Thiruvananthapuram, Kerala, India.
}

\begin{abstract}
Costus picatus (Costaceae) leaves and the whole plant of Coccinia indica (Cucurbitaceae) are used in the treatment of diabetes mellitus in Indian ethnic system of medicine. There are previous phytochemical reports from fruits, seeds, flowers and leaves of Coccinia indica. The stem has remained uninvestigated so far. Polar extract of Costus picatus has been investigated but the non-polar fractions have received scant attention. Since these plants are used as medicine for diabetes an examination of the stem of Coccinia indica and non polar fraction of Costus picatus are also found necessary. This work on the methanolic extract of the stem of Coccinia indica and the hexane extract of the leaves of Costus picatus reports the isolation of lupeol acetate, stigmasterol, $\beta$-sitosterol, and 3 $3,24,25$ - trihydroxycycloartane from Costus picatus and docos1-ol, docos-8-one, $\beta$-sitosterol and betulin from Coccinia indica. Docos-1-ol and docos-8-one are being reported for the first time from natural source and lupeol acetate, stigmasterol, 33, 24, 25- trihydroxycycloartane and betulin for the first time from these plants. The structure elucidations were done by IR, ${ }^{1} \mathrm{HNMR},{ }^{13} \mathrm{C} N M R,{ }^{1} \mathrm{H}-{ }^{13} \mathrm{C}$ INEPT NMR and FAB MS techniques. The radical scavenging activities of the extracts were studied with DPPH using UV-Visible bio spectrophotometer. The radical scavenging activity of Costus picatus is not reported till date.
\end{abstract}

Keywords: Costus picatus, Costaceae, Coccinia indica, Cucurbitaceae, terpenes, sterols, new linear compounds, radical scavenging activities

E-mail: ajithamgcollege@gmail.com

\section{INTRODUCTION}

Coccinia indica and Costus picatus are used as traditional medicines for the treatment of diabetes mellitus. ${ }^{[1]}$ Costus picatus is used in Brazilian traditional medicine to expel kidney stones. ${ }^{[2,3]}$ Coccinia indica leaves were used for the treatment of patients with untreated but uncomplicated maturity-onset diabetes. ${ }^{[4]}$ Fruits of Coccinia indica exhibited antibacterial activity against pathogenic bacteria and the juice of the stem is dripped into the eyes to treat cataracts. The plant is used internally in the treatment of gonorrhoea, gastrointestinal disturbances, liver weakness, dysentery, vomiting, chronic cough, bronchitis and asthma. ${ }^{[]]}$

There are phytochemical reports of the isolation of flavanoid glycosides ${ }^{[6]}$, polysaccharides ${ }^{[7]}$, steroidal saponins ${ }^{[8]}$ from the alcoholic extracts of Costus picatus. Chemical studies on Coccinia indica reports aminoacids, ascorbic acid, sterols, triterpenes, $\beta$-carotene and alkaloids. ${ }^{\left[{ }^{[9]}\right.}$ There are some unauthenticated reports that continuous use of Costus picatus as drug for diabetes may lead to unconsciousness. This work concentrates on the phytochemical analysis of the hexane fraction of the leaves of Costuspicatus and methanolic extract of the bark of Coccinia indica, since raw leaves of Costus picatus and whole plant of Coccinia indica are used as medicine. ${ }^{[1]}$ The radical scavenging activity of the extracts were measured and the results show that Coccinia indica has higher activity and hence may be a better medicine for diabetes which is supported by earlier clinical research also. ${ }^{[4]}$

\section{MATERIALS AND METHODS}

\section{Plant material}

Leaves of Costus picatus and bark of Coccinia indica were collected from Trivandrum district and voucher specimens are deposited in the chemistry research laboratory of M.G. College, Trivandrum. 


\section{Spectral analysis}

NMR spectra were measured in Bruker 300 or $500 \mathrm{MHz}$ spectrometer using $\mathrm{CDCl}_{3}$ as solvent and TMS as internal standard. IR spectra were recorded in Beckmann spectrometer and Mass spectra in JEOL JMS600 spectrometer. Radical scavenging activities were done by DPPH method using trolox as standard. The absorbances were measured with a UV-Visible Bio Spectrophotometer BL 198.

\section{Extraction and isolation}

$500 \mathrm{~g}$ of Costus picatus leaves were collected, dried in the shade and was repeatedly extracted with hexane at room temperature to get $25 \mathrm{~g}$ crude extract. $20 \mathrm{~g}$ of this extract was chromatographed on a column of silica and eluted with solvents of increasing polarities such as hexane, chloroform, ethylacetate and their mixtures. Four compounds were isolated from Costus picatus. $500 \mathrm{~g}$ of Coccinia indica bark was collected, dried and extracted with methanol to get $24 \mathrm{~g}$ of extract. $20 \mathrm{~g}$ of this was fractionated as above to yield four compounds. The isolates were identified by spectral techniques. Compounds 1-4 were isolated from Costus picatus and the compounds 5-7 are the isolates from Coccinia indica.

\section{RESULTS AND DISCUSSION}

Compound 1(Figure 1), was obtained as a white amorphous solid from hexane- $20 \%$ chloroform mixture and crystallised in chloroform-methanol as colourless needles with melting point $215^{\circ} \mathrm{C}$. It showed positive test for triterpenes in Liebermann Burchard reaction. ${ }^{1} \mathrm{H}$ NMR $\left(500 \mathrm{MH}_{z}\right)$ spectrum (Table 1) of 1 exhibited six methyl singlets between $\delta$ 0.79- 1.03 and a vinylic methyl at $\delta 1.68 \mathrm{ppm}$. It was identified as a triterpene acetate due to the presence of an acetate methyl signal at $\delta 2.04$ as a singlet and another one proton signal at $\delta 4.47$ as $\mathrm{dd}$, $\mathrm{J}=$ $4.5,0.6 \mathrm{H}_{\mathrm{z}}$. Presence of two exo-methylene broad singlets at $\delta 4.57$ and 4.69 in addition to the methyl signals already discussed pointed out to a lupane skeleton. Analysis of ${ }^{13} \mathrm{C}$ NMR spectrum (Table 2) showed the presence of 32 carbon atoms indicating a mono acetyl derivative. It was supported by signals at $\delta 171.08$ (OAc) and 81.01 (C-3). ${ }^{1} \mathrm{H}$ and ${ }^{13} \mathrm{C}$ NMR spectral data and melting point were in agreement with those reported for lupeol acetate ${ }^{10}$ and so compound 1 was identified as lupeol acetate.

Compound 2(Figure 2), was also isolated from hexane $-25 \%$ chloroform mixture. Liebermann Burchard reaction indicated a sterol. ${ }^{1} \mathrm{HNMR}$ spectrum(Table 1) consisted of two methyl singlets at $\delta 0.69$ and 1.00 , methyl doublets at $0.71,0.87$ and 1.01 and a methyl triplet at $\delta$

Table 1. ${ }^{1} \mathrm{H}$ NMR spectroscopic data for compounds 1-4 and $7\left(300,500 \mathrm{MH}_{\mathrm{z}}, \mathrm{CDCl}_{3}\right)$

\begin{tabular}{|c|c|c|c|c|c|}
\hline Position 1 & 2 & 3 & 4 & 7 & \\
\hline $\mathrm{H}-3$ & $4.47 \mathrm{dd}(4.5,0.6)$ & $3.51 \mathrm{~m}$ & 3.52 septet & $3.27 \mathrm{~m}$ & $3.18 \mathrm{~m}$ \\
\hline $\mathrm{H}-6$ & - & $5.35 \mathrm{~m}$ & $5.30 \mathrm{~m}$ & - & - \\
\hline $\mathrm{H}-18$ & - & $0.69 \mathrm{~s}$ & $0.68 \mathrm{~s}$ & $0.97 \mathrm{~s}-$ & \\
\hline \multirow[t]{2}{*}{$\mathrm{H}-19$} & $2.35 \mathrm{~m}$ & $1.00 \mathrm{~s}$ & $1.01 \mathrm{~s}$ & $0.34 d(5.4)$ & $2.35 \mathrm{td}(11.3,5.4)$ \\
\hline & & & & $0.55 d(5.4)$ & \\
\hline $\mathrm{H}-21$ & - & $1.01 \mathrm{~d}(6.3)$ & $0.92 \mathrm{~d}(5)$ & $0.88 d(6.3)$ & - \\
\hline $\mathrm{H}-22$ & - & $5.15 \mathrm{dd}(8.0,3.0)$ & - & - & - \\
\hline $\mathrm{H}-23$ & $0.93 \mathrm{~s}$ & $5.03 \mathrm{dd}(8.0,3.0)$ & - & - & $0.97 \mathrm{~s}$ \\
\hline $\mathrm{H}-24$ & $0.77 \mathrm{~s}$ & - & - & $3.31 \mathrm{~m}$ & $0.76 \mathrm{~s}$ \\
\hline $\mathrm{H}-25$ & $0.83 \mathrm{~s}$ & - & - & $-0.82 \mathrm{~s}$ & \\
\hline $\mathrm{H}-26$ & $1.03 \mathrm{~s}$ & $0.87 d(6)$ & $0.82 \mathrm{~d}(6.5)$ & $1.18 \mathrm{~s}$ & $1.02 \mathrm{~s}$ \\
\hline $\mathrm{H}-27$ & $0.96 \mathrm{~s}$ & $0.71 d(6)$ & $0.83 d(6.5)$ & $1.21 \mathrm{~s}$ & $0.98 \mathrm{~s}$ \\
\hline \multirow[t]{2}{*}{$\mathrm{H}-28$} & $0.79 \mathrm{~s}$ & - & - & $0.90 \mathrm{~s}$ & $3.79 \mathrm{~d}(10.8)$ \\
\hline & & & & & $3.33 d(10.8)$ \\
\hline $\mathrm{H}-29$ & 4.67brs & $0.80 \mathrm{~m}$ & - & $0,97 \mathrm{~s}$ & $4.68 \mathrm{brs}$ \\
\hline $4.57 \mathrm{brs}$ & $4.58 \mathrm{brs}$ & & & & \\
\hline $\mathrm{H}-30$ & $1.68 \mathrm{~s}$ & - & - & $0.80 \mathrm{~s}$ & $1.68 \mathrm{~s}$ \\
\hline $\mathrm{OAc}$ & $2.05 \mathrm{~s}$ & - & - & - & - \\
\hline
\end{tabular}


0.80 . Three olefinic protons were present at $\delta 5.35(1 \mathrm{H}, \mathrm{m})$, $5.15\left(1 \mathrm{H}, \mathrm{dd}, 8.0,3.0 \mathrm{H}_{\mathrm{z}}\right)$ and $5.03\left(1 \mathrm{H}, \mathrm{dd}, 8.0,3.0 \mathrm{H}_{\mathrm{z}}\right) . \mathrm{A}$ carbinolic proton resonated at $\delta 3.51$ as a multiplet. ${ }^{13} \mathrm{C}$ NMR spectrum(Table 2) showed the presence of a carbinolic carbon and two double bonds by the absorptions at $\delta 71.83,140.66,121.72,138.32$ and 129.31 . Comparison of these chemical shifts with literature ${ }^{11}$ showed that compound $\mathbf{2}$ is stigmasterol.

Compound 3(Figure 3), was also isolated using 1:1 hexane -chloroform mixture as white needles with melting point $135^{\circ} \mathrm{C}$. Liebermann - Burchard reaction indicated sterol nature. Comparison of ${ }^{1} \mathrm{H}$ (Table 1) and ${ }^{13} \mathrm{C}$ NMR(Table 2) data identified the compound as $\beta$-sitosterol ${ }^{11}$.

Compound 4(Figure 4), was obtained from a mixture of chloroform and $20 \%$ ethyl acetate as white amorphous powder. It crystallised in the same solvent to yield white crystals, melted at $185^{\circ} \mathrm{C}$ and gave positive test for a triterpene in Liebermann-Burchard reaction. IR spectrum showed bands for hydroxyl group $\left(3600 \mathrm{~cm}^{-1}\right)$ and cyclopropane ring $\left(3040 \mathrm{~cm}^{-1}\right)$. The ${ }^{1} \mathrm{H}$ NMR spectrum revealed the presence of six tertiary methyl groups at $\delta$ $0.97,1.18,1.21,0.90,0.97$ and 0.80 . A secondary methyl group was present at $\delta 0.88\left(\mathrm{~J}=6.3 \mathrm{H}_{z}\right)$. In addition to the above signals a highly shielded signal of $\mathrm{AB}$ pattern was also present at $\delta 0.34$ and 0.55 , each as $1 \mathrm{H}, \mathrm{d}, \mathrm{J}=5.4 \mathrm{~Hz}$, characteristic for a cyclopropane ring. Two carbinolic proton signals were present at $\delta 3.27(1 \mathrm{H}, \mathrm{m})$ and $3.31(1 \mathrm{H}, \mathrm{m})$. Deshielded tertiary methyls at $\delta 1.18$ and 1.21 showed the presence of $\left(\mathrm{CH}_{3}\right)_{2} \mathrm{C}-\mathrm{OH}$ grouping in the molecule. The ${ }^{13} \mathrm{C}$ NMR spectrum has 30 carbons from which seven $\mathrm{CH}_{3}$ carbons, eleven $\mathrm{CH}_{2}$ carbons, six $\mathrm{CH}$ carbons and six quaternary carbons were identified by the ${ }^{1} \mathrm{H}_{-}{ }^{13} \mathrm{C}$ INEPT NMR spectrum $\left(67.5 \mathrm{MH}_{z}\right)$. The presence of two secondary hydroxyl groups was evident from the two carbinolic carbon shifts at $\delta 78.8$ and 79.6 and a tertiary hydroxyl group from a hydroxylated quaternary carbon at $\delta 73.2$. Comparison of these spectral values with literature ${ }^{12}$ revealed compound 4 to be $3 \beta$, 24, 25-trihydroxycycloartane. This is the first report of a triterpene with cycloartane skeleton from Costus picatus.

Elution of the column of Coccinia indica with hexane-20\% chloroform yielded compound 5 (Figure 5) as white amorphous powder. It crystallised in chloroformmethanol mixture and melted at $76^{\circ} \mathrm{C}$. IR spectrum of the compound showed the presence of alcoholic group at $3276 \mathrm{~cm}^{-1} .{ }^{1} \mathrm{H}$ NMR spectrum showed a signal characteristic of two primary alcoholic protons at $\delta 3.50$ $(2 \mathrm{H}, \mathrm{brs})$ and a methyl triplet at $\delta 0.86$. The linear nature of the compound was revealed by the multiplets at $\delta 1.56(26 \mathrm{H})$ and $1.25(14 \mathrm{H}) \cdot{ }^{13} \mathrm{C} \mathrm{NMR}$ spectrum $\left(300 \mathrm{MH}_{7}\right)$ had a primary alcoholic carbon signal at $\delta 63.2 \mathrm{ppm}$ and

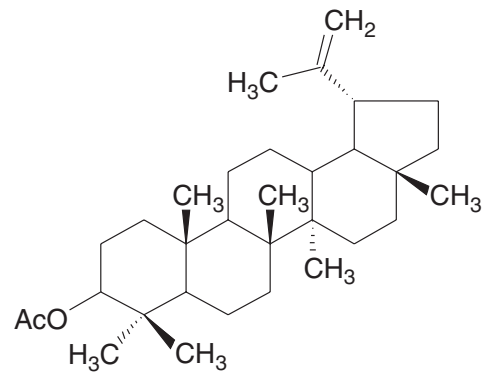

Figure $1 \&$ Figure 2

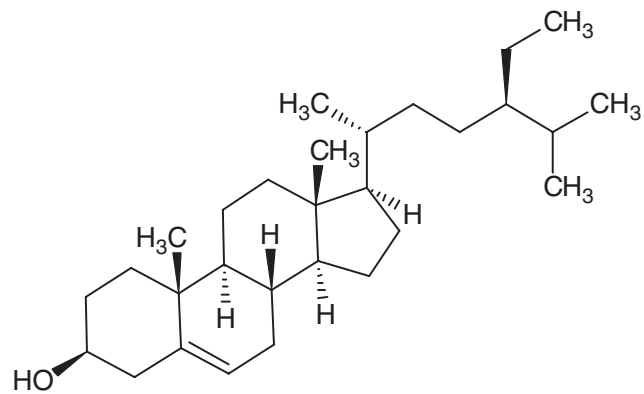

Figure 3 \& Figure 4.<smiles>CCC(/C=C/[C@H](C)C1CCC2C3CC=C4CC(O)CC[C@]4(C)C3CC[C@@]21C)C(C)C</smiles><smiles>CC(CCC(O)C(C)(C)O)C1CC[C@]2(C)C3CCC4C(C)(C)[C@@H](O)CCC45CC35CC[C@]12C</smiles> 
Table 2. ${ }^{13} \mathrm{C}$ NMR spectroscopic data for compounds $1-4$ and 7 (75, $125 \mathrm{MH}_{2}, \mathrm{CDCl}_{3}$ )

\begin{tabular}{|c|c|c|c|c|c|}
\hline Position & 1 & 2 & 3 & $4^{*}$ & 7 \\
\hline$C-1$ & 38.61 & 32.81 & 37.26 & 32.0 & 38.67 \\
\hline C-2 & 21.70 & 34.30 & 31.65 & 30.4 & 27.04 \\
\hline C-3 & 81.21 & 79.02 & 71.81 & 78.8 & 78.97 \\
\hline C-4 & 38.00 & 42.11 & 42.29 & 40.5 & 38.87 \\
\hline$C-5$ & 55.61 & 154.50 & 140.75 & 47.1 & 55.27 \\
\hline C-6 & 18.42 & 124.30 & 121.71 & 21.1 & 18.27 \\
\hline C-7 & 34.40 & 31.31 & 31.90 & 28.10 & 34.21 \\
\hline C-8 & 41.00 & 28.72 & 31.90 & 48.61 & 40.89 \\
\hline C-9 & 50.51 & 42.11 & 50.14 & 20.00 & 50.37 \\
\hline C-10 & 37.31 & 39.70 & 36.51 & 25.81 & 37.13 \\
\hline C-11 & 21.12 & 19.31 & 21.09 & 25.81 & 20.79 \\
\hline C-12 & 24.01 & 31.60 & 39.78 & 35.50 & 25.15 \\
\hline C-13 & 36.20 & 40.61 & 42.33 & 45.30 & 37.29 \\
\hline C-14 & 43.00 & 47.61 & 56.77 & 48.71 & 42.69 \\
\hline C-15 & 25.31 & 21.30 & 24.29 & 33.51 & 27.35 \\
\hline C-16 & 35.81 & 21.41 & 28.24 & 26.70 & 29.16 \\
\hline C-17 & 43.22 & 48.42 & 56.06 & 52.32 & 47.77 \\
\hline C-18 & 48.51 & 18.31 & 11.99 & 18.11 & 48.72 \\
\hline C-19 & 48.20 & 18.21 & 19.39 & 29.11 & 47.77 \\
\hline C-20 & 151.21 & 33.30 & 36.15 & 36.40 & 150.46 \\
\hline C-21 & 30.00 & 17.41 & 18.27 & 18.31 & 29.76 \\
\hline C-22 & 40.21 & 107.00 & 39.95 & 32.80 & 33.93 \\
\hline C-23 & 27.61 & 139.4 & 26.09 & 28.70 & 27.95 \\
\hline C-24 & 16.71 & 47.60 & 45.84 & 79.61 & 15.35 \\
\hline C-25 & 16.40 & 30.51 & 29.16 & 73.20 & 16.09 \\
\hline C-26 & 16.22 & 20.21 & 19.81 & 26.52 & 15.94 \\
\hline C-27 & 14.71 & 20.10 & 19.03 & 23.21 & 14.75 \\
\hline C-28 & 18.20 & 25.51 & 23.07 & 19.31 & 60.58 \\
\hline C-29 & 109.60 & 12.21 & 11.86 & 14.00 & 109.69 \\
\hline C-30 & 19.51 & - & - & 25.41 & 19.05 \\
\hline C-31 & 171.31 & - & - & - & - \\
\hline C-32 & 28.22 & - & - & - & - \\
\hline
\end{tabular}

*Multiplicities were determined by ${ }^{1} \mathrm{H}-{ }^{13} \mathrm{C}$ NMR INEPT experiment

21 shielded carbon atoms in the range of $\delta 22.70-$ 53.12ppm. Detailed analysis of IR, ${ }^{1} \mathrm{H}$ and ${ }^{13} \mathrm{C}$ NMR spectra showed compound $\mathbf{5}$ to be a primary alcohol with twenty two carbon atoms in a chain. FABMS did not furnish a molecular ion peak; instead a $\left(\mathrm{M}^{+}+3 \mathrm{H}\right)$ peak was present at $\mathrm{m} / \mathrm{z} 329$. $\left(\mathrm{M}^{+}+3 \mathrm{H}\right)$ peak is common for long chain aliphatic alcohols. Base peak was observed at $\mathrm{m} / \mathrm{z} 154$ due to the rupture of C-11 and C-12 bond. Fragment at $\mathrm{m} / \mathrm{z} 168$ (12.5) due to the breaking of C-10 and $\mathrm{C}-11$ bond with the loss of one water molecule appeared at $\mathrm{m} / \mathrm{z} 139$ (25). Other significant fragments are shown in Fig 5. Analysis of FABMS suggested that 
compound $\mathbf{5}$ is docosan-1-ol $\left(\mathrm{MF} \mathrm{C}_{22} \mathrm{H}_{46} \mathrm{O}\right)$ which is a new natural compound.

Compound $\mathbf{6}$ (Figure 6), isolated as white crystals from hexane- $40 \%$ chloroform with melting point $69^{\circ} \mathrm{C}$ exhibited the characteristic absorptions of a linear ketone in the IR at 1719, 2908, 2848,1470,1458 $\mathrm{cm}^{-1}$. It was further confirmed by the peaks in the ${ }^{1} \mathrm{H}$ NMR spectrum $\left(300 \mathrm{MH}_{\mathrm{z}}\right)$ at $\delta 2.35(2 \mathrm{H}, \mathrm{m})$ and $2.17(\mathrm{~m})$, the latter being the characteristic absorptions for protons adjacent to the keto group. Signal at $\delta 2.17(\mathrm{~m})$ was found merged with signals of other shielded protons. Remaining protons were between $\delta 1.25$ and 1.64 as multiplets. Presence of two end methyl groups was shown by a six proton triplet at $\delta 0.88 \mathrm{ppm} .{ }^{13} \mathrm{C}$ NMR signals were seen at $\delta 179.12$ (keto group) and between 14.11-33.89 ppm (21 carbon atoms). FABMS gave a molecular ion peak at $\mathrm{m} / \mathrm{z} 324(10)$. The position of keto group was fixed at C-10 due to the presence of fragment ions at $\mathrm{m} / \mathrm{z} 170(75)$ and 197 (25) formed by the cleavage of bonds adjacent to the keto group. Another important peak was found at m/z 154(85) which was formed by the cleavage of $\alpha-\beta$ bond, a characteristic feature of aliphatic ketones. Other fragments were at $\mathrm{m} / \mathrm{z} 238(12.5)$ for the rupture of C-6 and C7 bond and at 294(12.5) for C-2 and C-3. The compound was thus identified as docos-10-one $\left(\mathrm{MF} \mathrm{C}_{22} \mathrm{H}_{44} \mathrm{O}\right)$ whixh is a new natural compound.

Compound 7 (Figure 7), isolated as white crystals from chloroform fractions and melted at $235^{\circ} \mathrm{C}$. It was positive to Liebermann-Burchard reaction for triterpenes. General features of ${ }^{1} \mathrm{H}$ NMR spectrum (Table 1 ) indicated again a lupane skeleton. Comparison of ${ }^{1} \mathrm{H}$ NMR signals with those of compound 1 revealed the absence of acetate methyl signal in 7 . The shift of the $3-\mathrm{H}$ absorption from $4.47(1 \mathrm{H}, \mathrm{m})$ in 1 to $\delta 3.18(1 \mathrm{H}, \mathrm{m})$ in 7 shows the hydroxylation at $\mathrm{C}-3$. Another feature noticed was the absence of a tertiary methyl signal at $\delta 0.79$ (C- 28), and the appearance of two one proton doublets at $\delta 3.79$ $\left(\mathrm{J}=10.8 \mathrm{H}_{z}\right)$ and $3.33\left(\mathrm{~J}=10.8 \mathrm{H}_{z}\right)$. This may be due to a $\mathrm{CH}_{2} \mathrm{OH}$ grouping at $\mathrm{C}-28 .{ }^{13} \mathrm{C}$ NMR spectrum (Table 2) matched with that of lupeol except for the presence of an additional carbinolic carbon at $\delta 60.58 \mathrm{ppm}$. Chemical shift at $\delta 60.58 \mathrm{ppm}$ points to the oxidation of methyl group at C-28 in $\mathbf{1}$ to a primary alcohol in 7. Comparison of these spectral values with literature ${ }^{13}$ showed that compound $\mathbf{7}$ is betulin (lupane skeleton).

$\beta$-sitosterol also was isolated from Coccinia indica which was identified by comparison of physical properties and ${ }^{1}$ HNMR spectrum with those of an authentic sample.

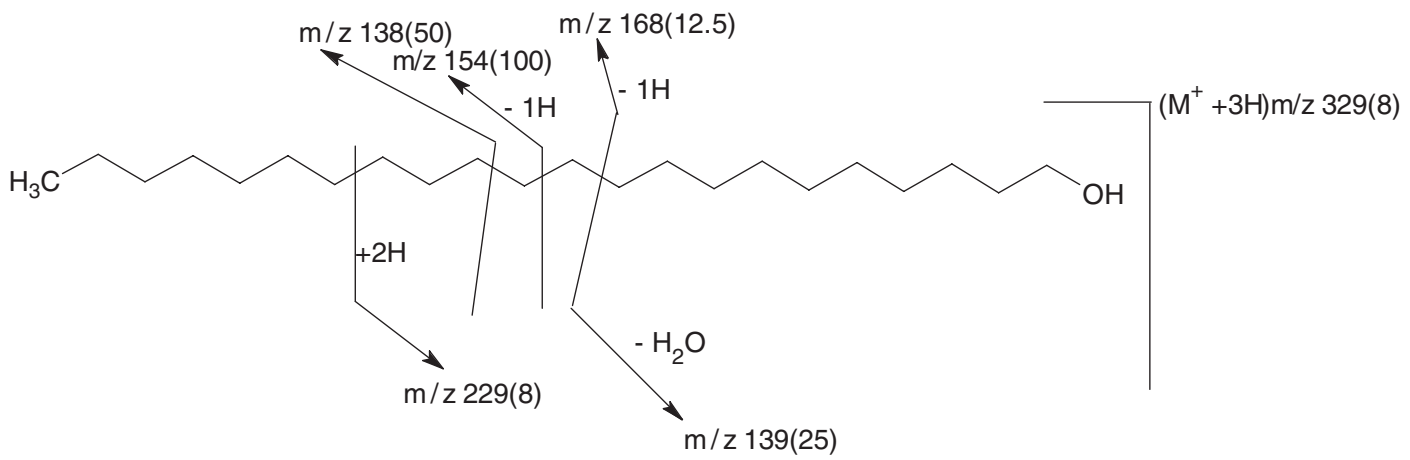

Figure 5. Mass spectral fragmentation of compound $\mathbf{5}$.

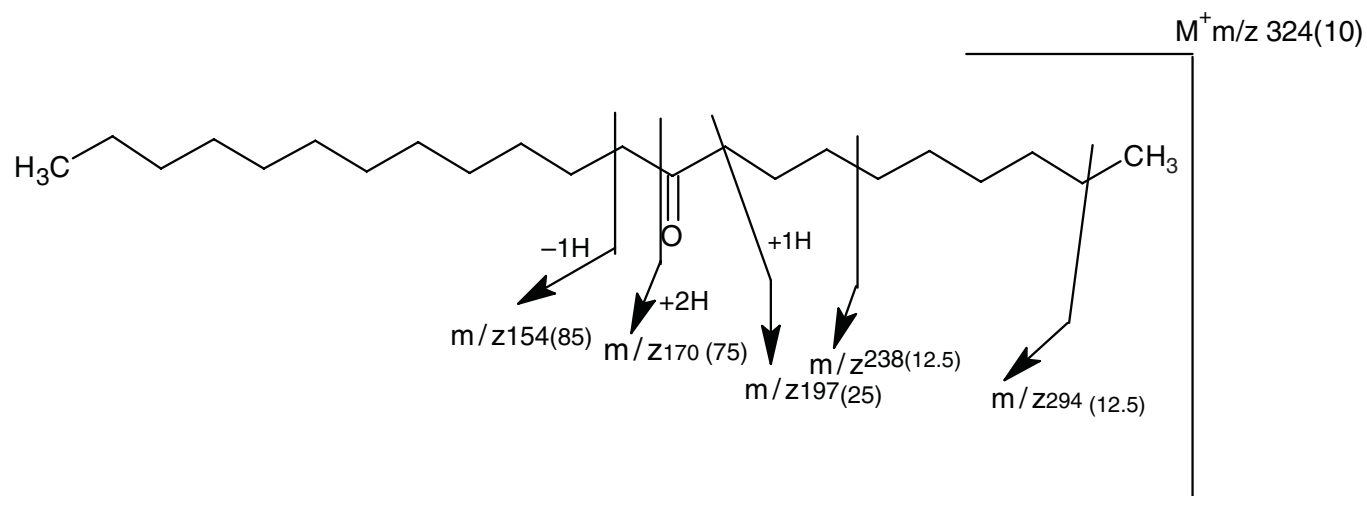

Figure 6. Mass spectral fragmentation of compound 6. 


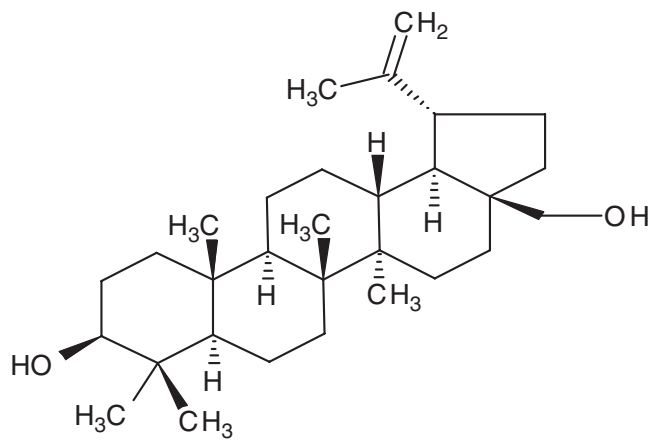

Figure 7

Both the plant extracts are showing good radical scavenging activities in the range of $30-35 \%$ as that of trolox indicating the presence of some very active antioxidant principles in the plants. Coccinia indica is found to be a little more effective radical scavenger than Costus picatus in this respect.

\section{MEASUREMENT OF RADICAL SCAVENGING ACTIVITIES}

Radical scavenging activities of the extracts were measured by DPPH (Diphenyl picryl hydrazyl free radical) method using trolox (6-hydroxy-2,5,7,8-tetramethylchroman-2carboxylic acid) as the standard. Ethylacetate extract of Costus picatus and methanolic extract of Coccinia indica were mixed separately with fixed concentrations of DPPH. The absorbance was measured using a UV-Visible Bio Spectrophotometr BL 198 at the $\lambda_{\text {max }}$ of DPPH (518nm). Antioxidant activities were measured in terms of $\mathrm{IC}_{50}, \%$ inhibition and TEAC values. $\mathrm{IC}_{50}$ is the concentration of the sample needed to reduce the absorption of DPPH to its half value. Percentage inhibition and TEAC ae calculated using the following relations.

$\begin{aligned} & \text { Percentage } \\ & \text { inhibition }\end{aligned}=\frac{\text { Absorption of DPPH-Absorption of sample }}{\text { Absorption of DPPH Trolox }} \times 100$

TEAC $=\frac{\text { Percentage inhibition of the sample }}{\text { Percentage inhibition of the sample }}$

The absorbance of DPPH solutions, DPPH -trolox mixtures and DPPH sample mixtures were measured at 518 nm. Graphs were plotted with absorbance along $\mathrm{Y}$-axis and concentration along the $\mathrm{X}$-axis for all samples. Using the formula for straight line, $\mathrm{y}=\mathrm{mx}+\mathrm{c}, \%$ inhibition and $\mathrm{IC}_{50}$ were calculated. From the $\%$ inhibitions of extracts and trolox, TEAC also was calculated. Results obtained are given in the Table 3 .
Table 3. Comparison of the radical scavenging activities of Trolox, extracts of Coccinia indica and Costus picatus

\begin{tabular}{ccccc}
\hline No & Sample & IC50 & $\begin{array}{c}\% \\
\text { Inhibition }\end{array}$ & TEAC \\
\hline 1 & Trolox & 0.567 & 88.33 & 1 \\
2 & Coccinia indica & 240.23 & 30.38 & 0.344 \\
3 & Costus picatus & 472.04 & 25.18 & 0.285 \\
\hline
\end{tabular}

\section{ACTIVITY DISCUSSION}

The use of antioxidant principles in the treatment of diabetes is well documented ${ }^{[1-4]}$.The antioxidant materials help in the repair and rejuvenation of $\beta$ cells that are damaged in diabetic patients. The significant activity exhibited by the crude extracts indicate the presence of some very active antioxidant principles, which may have activity greater than if not equal to trolox itself, in the plant. The effectiveness of lupane ${ }^{[14]}$, cucurbitacin ${ }^{[15]}$,ursane ${ }^{[17]}$ triterpenes and bacosin ${ }^{[16]}$ in the treatment of diabetes has been clinically verified. The capacity of lupeol derivatives to inhibit the melanin production in melanoma cells is extensively studied. ${ }^{[14]}$ This effect may be used for combating the hyperpigmentation due to acanthosis nigricans in diabetic patients with insulin resistance. The presence of large number of lupane triterpenes in the plants under study assumes special importance in this context.

\section{CONCLUSION}

From two plants we have isolated eight compounds. Two linear compounds isolated from Coccinia indica were new. Three triterpenes and sitgmasterol are reported for the first time from these plants. Only $\beta$-sitosterol isolated from the two plants is previously reported. Radical scavenging activity results show that Coccinia indica is having higher antioxidant capacity that of Costus picatus, hence the former can be recommended as a better medicine for diabetes.

\section{ACKNOWLEDGEMENTS}

Ajithabai MD and Jayakumar G thank KSCSTE , Trivandrum, Kerala, India for financial aid, Sreedevi $S$ and Deepa PN Nair University of Kerala, Trivandrum for research fellowship and Sunitharani SP, UGC for research fellowship. 


\section{REFERENCES}

1. Jayakumar G, Ajithabai MD, Sreedevi S, Viswanathan PK, Rameshkumar B. Ethnobotanical survey of the plants used in the treatment of diabetes. Indian Journal of Traditional Knowledge 2010;9(1):100-4.

2. Souzaa AM, Laraa LS, Previatoa JO, Lopesa AG, Nevesa CC, Silvab BP, et al. Modulation of Sodium Pumps by Steroidal Saponins. Z. Naturforsch. 2004; 59C, 432D:436-9.

3. Keller AC, Vandebroek, Liu Y, Balick MJ, Kronenberg F, Kennelly EJ, et al. Costus picatus tea failed to improve diabetic progression in Mice. Am. J. Ethanopharmacology. 2009;121(2):248-54.

4. Shibib BA, Khan LA, Rahman R. Hypoglycaemic activity of Coccinia indica and Momordica charantia in diabetic rats: depression of the hepatic gluconeogenic enzymes glucose-6phosphatase and fructose-1,6-bisphosphatase and elevation of both liver and red-cell shunt enzyme glucose-6-phosphate dehydrogenase. Biochem J. 1993;15:267-70.

5. Umbreen F, Huma S, Shaukat M, Syed AL, Ghazala HR. Anti bacterial activities of Coccinia grandis L. Pak. J. Bot. 2008;40(3): 1259-1262.

6. Silva BP, Robson R, Bernardo, Jose P, Parante. Flavonol glycosides from Costus picatus. Phytochemistry. 2000;53(1):87-92.

7. Silva BP, Parente JP. Bioactive poly saccharides from Costus spicatus. Carbohydrate Polymers 2003;51(3):239-44.

8. Silva BP, Bernardo RR, Jose P, Parente. A furostanol glycoside from rhizomes of Costus spicatus. Phytochemistry. 1999;51(7): 931-4.

9. Syed ZS, Krishna B, Kandukuri V, SingaraCharya MA, Antimicrobial activity of the fruit extracts of Coccinia indica. African Journal of Biotechnology 2009;8(24):7073-6.
10. Jamal AK, Yaacob WA, Laily BD. A Chemical Study on Phyllanthus reticulates. Journal of Physical Science. 2008;19(2):45-50.

11. Rowshanul HM, Farjana N, Matiar RM, Ekramul HM, Rezaul KM. Isolation of stigmasterol and sitosterol from methanolic extract of bark of Calotropis gigantea Linn.

12. Pakistan Journal of Biological Sciences. 2007;10(22):4174-6.

13. Hisham A, Ajithabai MD, Jayakumar G, Mangalam SN, Fujimoto Y.Triterpenoids from Dysoxylum malabaricum. Phytochemistry. 2001; 56: 331-4.

14. Izabela JM, Jacek Lk, Izabela AS, Paweł K. Possible fungistatic implications of betulin presence in Betulaceae plants and their hymenochaetaceae parasitic fungi. Z. Naturforsch. 2010;65 c: 201-6.

15. Keishi Hata, Toshiyuki Mukaiyama, Noriyuki Tsujimura, Yusuke Sato, Yasuyuki Kosaka, Kenji Sakamoto, Kazuyuki Hori. Differentiation-Inducing Activities by Lupane Triterpenes from Lactuca indicaon a Mouse Melanoma Cell Line. Animal Cell Technology: Basic \& Applied Aspects. 2009;15:279-285.

16. Sook Young Lee, Seok Hyun Eom, Yong Kyoung Kim, Nam II Park, Sang Un Park.

17. Cucurbitane-type triterpenoids in Momordica charantia Linn. Journal of Medicinal Plants Research. 2009;3(13):1264-1269.

18. Ghosh T, Maity TK, Singh J. Antihyperglycemic activity of Bacosine, a Triterpene from Bacopa monnieri, in Alloxan-Induced Diabetic Rats.Planta Med. 2010; [Epub ahead of print]

19. Myung Sun Lee, Phuong Thien Thuong. Stimulation of Glucose Uptake by Triterpenoids from Weigela subsessilis. Phytother. Res. 2010;24:49-53. 